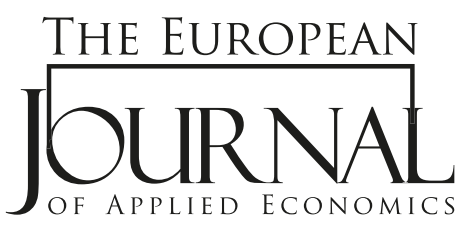

EJAE 2015, 12(1): 10-18

ISSN 2406-2588

UDK: 331.101.32:35.07(497.7)

DOI: 10.5937/EJAE12-8154

Original paper/Originalni naučni rad

\title{
PERCEIVED WORK ENVIRONMENT AND JOB SATISFACTION AMONG PUBLIC ADMINISTRATION EMPLOYEES
}

\author{
Marjan Bojadjiev ${ }^{1}$, Miodraga Stefanovska Petkovska ${ }^{1,}$, \\ Ana Tomovska Misoska ${ }^{1}$ Julijana Stojanovska ${ }^{2}$ \\ ${ }^{1}$ University American College Skopje \\ 60 Treta Makedonska Brigada Street, Skopje, Macedonia \\ ${ }^{2}$ City Hall of Skopje, \\ 82 Ilinden Street, Skopje, Macedonia
}

\begin{abstract}
:
This study examines the effects of the percieved work environment on public employee feelings of job satisfaction. Moreover, the paper will investigate the relationship between personal and job characteristics and job satisfaction. The data was collected from a sample of 169 employees working in one local government municipality in Macedonia. The results show that organizational climate and its components significantly predict job satisfaction among public administration employees. The results highlight that employee age acts as the most powerfull predictor of job satisfaction. The analysis of the perceived work environment suggests that recognition is a significant predictor of job satisfaction among public administration employees, followed by opportunities for professional advancement and work itself. The significance of this research lies in its contribution to the knowledge and understanding of determinants that could improve job satisfaction among public administration employees
\end{abstract} in developing economies.

\section{INTRODUCTION}

Job satisfaction has intrigued the academic community for more than five decades. By 1976, Locke registered 3,350 articles that covered the issue of job satisfaction, while three decades later, Ghawazzi (2008) estimated that this number increased to more than 12,000 articles. Researchers highlight that the popularity of this topic is primarily triggered by its multidisciplinary nature and multidimensional structure, targeting a variety of professions, industries and disciplines. (Ferdousi, 2012; Chien, 2013). In addition, various researchers suggest that it influences behaviour (Bowling, 2010), membership-related behaviour (Wright \& Davis, 2003), loyalty and tendency of employees to leave the organization (Tsai \& Huang, 2008; Rutherford et al., 2009; Savić et al., 2014), as well as the employee well-being (George \& Jones, 2008). Job satisfaction can be considered an important factor of work motivation, employee retention and performance, thus reducing the turnover and litigation rate (Kim, 2002).

The importance of job satisfaction in managing public administration employees has been a popular area of research in the developed economies based on the belief that the motivation of public administration employees directly affects the quality and content of public outputs (Perry \& Wise, 1990; Kim, 2002; Bullens \& Broeck, 2007). Research in this field ranged from the analysis of the relationship between job satisfaction and personal characteristics (Reiner \& Zhao, 1999; Bright, 2005; Dehart-Davis et al., 2007), work preferences (Bright, 2005), effectiveness of public-sector diversity management programs (Nigro \& Kellough, 2003), impact of perceptions (Scott \& Pandey, 2005), tendency for charitable giving (Houston, 2006), volunteering (Reed \& Selbee, 2001) and socio-economic status (Goss, 1999). Since 
the Theory of Public Service Motivation suggests that public administration employees are motivated by the commitment to the common good (Houston, 2006), researchers have investigated the importance of intrinsic $v s$. extrinsic rewards for this group of employees. The results suggest that public administration employees pay less attention to extrinsic motivators such as higher pay, and more to service to society and the importance of meaningful work (Jurkiewitz et al., 2004; Houston, 2006). Recognition, discrimination and external relations were the best explanatory variables for job satisfaction (Johnsrud \& Rosser, 1999). All of the above mentioned studies have been conducted in developed economies. However, public administration employees in developed economies work under more favorable conditions compared to their colleagues from developing economies. While the first work in an established system, have more opportunities for professional growth, and a wider scope for exploring one's talent etc., the latter are faced with numerous constrains (Ferdousi, 2012). The purpose of this research is to contribute to decreasing the existing research gap in understanding the determinants of job satisfaction among public administration employees in developing economies.

\section{METHODOLOGY}

\section{Research objectives and research model}

Research is modeled on the previous research done in the field (Kim, 2002; Smerek \& Peterson, 2007). It is constructed around the following research objectives:

1. to investigate the influence of personal and job characteristics on job satisfaction,

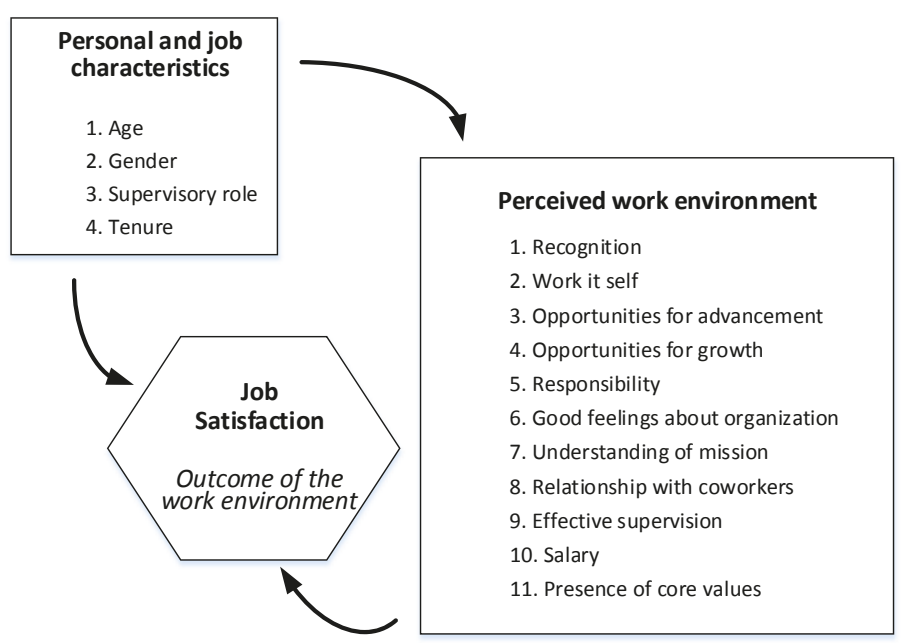

Figure 1. Conceptual model of the research
2. to assess the most significant predictors of job satisfaction.

The conceptual model of this research is illustrated in Figure 1. The dependent variable is job satisfaction and is considered an outcome of the work environment. Job satisfaction was measured based on the three items:

1. the extent to which the current job compares to the ideal job;

2. the extent to which it meets your initial expectations;

3. the overall satisfaction with your job.

In order to address research objectives, the model outlines the role of personal and job characteristics (age, tenure, supervisory role and gender) and investigates how each of these characteristics affects job satisfaction. In addition, the model incorporates eleven work environment factors and analyses their impact on job satisfaction.

\section{Research approach and sample}

In order to test the conceptual model of research and research objectives, a survey was administered among 169 employees working in local municipalities in the city of Skopje during the period SeptemberNovember, 2014. The research utilized a convenient sampling method that is considered appropriate for the exploratory studies underlying further research (Coolican, 2004). The distribution of survey questionnaires was done in person by a member of the research team. The respondents were asked to fill in the questionnaires and return them in a pick-up box. The survey was anonymous and no marks were printed on the questionnaires that could identify the respondents. Table 1 presents the demographic profile of the surveyed population.

\section{Instrument}

In order to better understand various aspects of workspace environment and job satisfaction among public administration employees in the Republic of Macedonia, a questionnaire modeled on the previous research by Smerek and Peterson (2007) and Kim (2000) was used in this study. The questionnaire contained a total of 43 questions covering the area of job satisfaction, advancement and growth, responsibility, autonomy, work perception, mission and core values of an organization, supervisor 
and colleague relationships, salary satisfaction, good feelings about the organization, work/life balance, training and development. All questions from the questionnaire were measured on a 5-point Likert type scale ranging from 1-strongly disagree to 5-strongly agree. Besides these questions, a section from the questionnaire collected the following personal and job characteristics of the participants: age, gender, supervisory role and tenure.

\begin{tabular}{|c|c|c|}
\hline Gender & No & Percentage \\
\hline Male & 50 & 29.6 \\
\hline Female & 119 & 70.4 \\
\hline \multicolumn{3}{|l|}{ Age } \\
\hline under 30 & 27 & 16.0 \\
\hline 30-39 years old & 80 & 47.3 \\
\hline $40-49$ years old & 29 & 17.2 \\
\hline $50-59$ years old & 27 & 16.0 \\
\hline 60 years old and above & 6 & 3.6 \\
\hline \multicolumn{3}{|l|}{ Education } \\
\hline Primary school & 1 & .6 \\
\hline High school & 16 & 9.5 \\
\hline College & 4 & 2.4 \\
\hline University & 131 & 77.5 \\
\hline Master's degree & 17 & 10.1 \\
\hline \multicolumn{3}{|l|}{ Tenure } \\
\hline less than 1 year & 6 & 3.6 \\
\hline $1-5$ years & 60 & 35.5 \\
\hline $5-10$ years & 77 & 45.6 \\
\hline more than 10 years & 26 & 15.4 \\
\hline \multicolumn{3}{|l|}{ Supervisory role } \\
\hline Supervisory role & 23 & 13.6 \\
\hline Non-supervisory role & 146 & 86.4 \\
\hline
\end{tabular}

Table 1. Demographic profile of participants

\section{ANALYSIS OF DATA}

Upon collecting research data, a principal component factor analysis (PCA) with direct oblimin rotation on job satisfaction and perceived work environment was performed in order to examine the factor structure of the data. The calculated KMO value was 0.831 , which was considered adequate for the factor analysis. The results indicate that the correlation matrix was adequate and that PCA can be performed. The items that did not clearly load into a single factor or did not have a minimal value of 0.7 , were excluded from the analysis. A total of 43 questions from the original 75, converged in eleven factors. Table 2 presents the reliability of results for each of the extracted factors.

In order to test research objectives, the following new variables were constructed: job satisfaction measured by three items; recognition measured by three items; work itself measured by four items; opportunities for promotion measured by three items; professional development opportunities measured by five items; responsibility measured by four items; good feelings measured by three items; clarity of mission measured by three items; relationship with coworkers measured by five items; effective supervision measured by six items; salary measured by two items and presence of core values measured by two items.

\section{RESULTS}

In order to address the first research objective, a t-test analysis was conducted to analyze the relationship of gender and supervisory role on job satisfaction (Table 3). The results from the t-test of gender with the perceived work environment indicate that overall females reported higher satisfaction levels with their workplace compared to males. Females were more satisfied with nine out of eleven workplace factors. It is interesting to note that women were less satisfied compared to their male colleagues with their opportunities for promotion. The greatest gender discrepancy was found in two items: effective supervision and core values, where females had much higher scores compared to their male colleagues. The analysis indicates significant statistical gender difference for four items: clarity of mission, relationship with co-workers, effective supervision and presence of core values.

Given that the assumption for homogeneity of variance was not fulfilled, we proceeded with performing the Mann-Whitney U-test of supervisory role with perceived work environment and job satisfaction. The results indicate that employees with supervisory role were more satisfied with four out of eleven workplace factors (recognition, opportunities for promotion, good feelings about the organization and effective supervision). In addition, they showed higher level of job satisfaction compared to the employees with non-supervisory roles. The greatest discrepancy was found in recognition, where employees with supervisory role had much higher scores compared to their colleagues. The analysis found significant statistical difference for two items: recognition and effective supervision. 
1 Imagine your ideal job. How well does your current position compare to the ideal job?

2 In general, how satisfied are you with your job?

3 Consider all the expectations you had when you started your current job. Does your current job meet those expectations?

\section{Recognition ( $\alpha=0.758$ )}

4 My contributions are valued by the members of my unit/department

5 I am satisfied with the received recognition or praise for doing good work

6 In my unit/department, you always get appropriate recognition when you have done something extraordinary

7 I enjoy my job

Work itself $(\alpha=0.847)$

8 My job is interesting

9 My job gives me a sense of accomplishment

10 The work I do is very important for my unit/department and the Organization as a whole

11 Opportunities for promotion within the Organization

12 I know what is requested from me in order to get promoted within the Organization

13 Information about job vacancies within the Organization is readily available

Professional Advancement Opportunities ( $\alpha=0.798$ )

$14 \mathrm{My}$ unit/department offers the appropriate training or education that I need to prosper in my job

15 I have received the necessary training to do my job wel

16 I have already had the opportunity at work to learn and grow

0.783

17 There is someone at work who encourages my development

18 My supervisor points out the training or education that I need to grow in my job

Responsibility $(\alpha=0.837)$

19 I have control over how I do my work

21 The physical environment allows me to do my job

22 I possess necessary resources, tools or equipment to do my job

Good Feelings about Organization ( $\alpha=0.868$ )

23 I feel a strong sense of belonging to the Organization

24 I have a strong commitment to the Organization

25 I am proud to work for the Organization

Clarity of Mission( $\alpha=0.922)$

26 I understand how my work supports the mission of my unit/department and the Organization as a whole and it is at complete service to the citizens.

27 I know what is expected of me at work.

28 The goals of my unit/department and the Organization as a whole are clear to me

29 I respect my co-workers and I trust them

30 I am consistently treated with respect by my co-workers

31 I can count on my co-workers to help me out when needed

32 My co-workers and I work as a team

33 My unit/department collaborates effectively with other units/departments within the Organization

\section{Effective Supervisor ( $\alpha=0.792)$}

34 My supervisor effectively communicates with the co-workers

35 My supervisor is an effective decision-maker for the Organization

36 My supervisor is approachable and easy to talk to

37 My supervisor gives me constructive feedback on my performance

38 My supervisor considers my ideas and remarks

39 My supervisor deals effectively with poor performance

Salary $(\alpha=0.784)$

40 I am satisfied and fairly paid for what I do

41 My salary/pay rate is a significant factor in my decision to stay at the Organization

\section{Presence of Core Values $(\alpha=0.881)$}

42 Organization fosters values that are clear and understandable to all employees (e.g. coming to work on time, code of ethics, etc.)

43 The fulfillment of my duties and obligations is of great importance for the Organization as a whole

Table 2. PCA of perceived work environment and job satisfaction 
The results of the performed correlation of age and tenure with the eleven workplace factors and job satisfaction are presented in Table 4. The age of employees has a significant positive correlation with effective supervision, recognition and job satisfaction. This means that job satisfaction, effective supervision and recognition increase along with the employee age. On the other hand, the longer the tenure of employees in the organization, the less satisfied they are with the opportunities for professional advancement, good feelings about the organization and presence of core values.

Research results indicate that employees with tenure over 10 years had the highest level of job satisfaction and were more satisfied with five out of eleven workplace factors (recognition, salary, relationship with coworkers, responsibility) (Table 5). This group of employees had the same level of satisfaction with the work itself as the employees who were employed in the company for less than a year. It is interesting to note that the employees who were employed in the company for less than one year at the time of the survey, showed the highest level of satisfaction with the following items compared to their colleagues: opportunities for advancement, good feelings about organization, opportunities for growth, mission and presence of core value. The Kruskal-Wallis analysis found significant statistical difference for two items: mission and presence of core value.

In order to address the second research objective, a multiple regression model was designed to evaluate the relative impact of the eleven work environment factors controlling personal and job characteristics.

\begin{tabular}{|c|c|c|c|c|c|c|c|c|}
\hline Variable & Gender & Mean & $\begin{array}{c}\text { Std. } \\
\text { Deviation }\end{array}$ & Sig. & Supervisory role & Mean & $\begin{array}{c}\text { Std. } \\
\text { Deviation }\end{array}$ & $\begin{array}{c}\text { Mann } \\
\text { Whitney } \\
\text { U test } \\
\text { Sig. }\end{array}$ \\
\hline \multirow{2}{*}{ JS } & male & 2.98 & 0.89 & & Supervisor & 3.39 & 0.68 & 0.068 \\
\hline & female & 3.17 & 0.70 & & Non-supervisor & 3.09 & 0.82 & \\
\hline \multirow{2}{*}{ recognition } & male & 3.15 & 0.79 & & Supervisor & 3.57 & 0.72 & $.012 *$ \\
\hline & female & 3.25 & 0.81 & & Non-supervisor & 3.09 & 0.77 & \\
\hline \multirow{2}{*}{ workitself } & male & 3.81 & 0.49 & & Supervisor & 3.84 & 0.59 & 0.803 \\
\hline & female & 3.87 & 0.51 & & Non-supervisor & 3.86 & 0.47 & \\
\hline \multirow{2}{*}{ advancement } & male & 3.31 & 0.71 & & Supervisor & 3.22 & 0.68 & 0.122 \\
\hline & female & 3.46 & 0.64 & & Non-supervisor & 3.41 & 0.62 & \\
\hline \multirow{2}{*}{ growth } & male & 3.20 & 0.58 & & Supervisor & 3.26 & 0.62 & 0.203 \\
\hline & female & 3.08 & 0.68 & & Non-supervisor & 3.06 & 0.64 & \\
\hline \multirow{2}{*}{ responsibility } & male & 3.60 & 0.60 & & Supervisor & 3.49 & 0.57 & 0.053 \\
\hline & female & 3.69 & 0.56 & & Non-supervisor & 3.68 & 0.59 & \\
\hline \multirow{2}{*}{ goodfeelings } & male & 3.80 & 0.77 & & Supervisor & 3.87 & 0.63 & 0.641 \\
\hline & female & 3.85 & 0.52 & & Non-supervisor & 3.79 & 0.58 & \\
\hline \multirow{2}{*}{ mission } & male & 3.83 & 0.62 & $*$ & Supervisor & 3.90 & 0.42 & 0.190 \\
\hline & female & 4.06 & 0.41 & & Non-supervisor & 4.01 & 0.46 & \\
\hline \multirow{2}{*}{ coworkers } & male & 3.63 & 0.64 & $*$ & Supervisor & 3.57 & 0.60 & 0.176 \\
\hline & female & 3.84 & 0.53 & & Non-supervisor & 3.85 & 0.54 & \\
\hline \multirow{2}{*}{ supervisor } & male & 3.41 & 0.69 & $*$ & Supervisor & 3.70 & 0.67 & 0.109 \\
\hline & female & 3.67 & 0.67 & & Non-supervisor & 3.49 & 0.65 & \\
\hline \multirow{2}{*}{ salary } & male & 2.87 & 0.62 & & Supervisor & 2.78 & 0.62 & 0.327 \\
\hline & female & 2.94 & 0.76 & & Non-supervisor & 2.88 & 0.71 & \\
\hline \multirow{2}{*}{ values } & male & 3.63 & 0.77 & $*$ & Supervisor & 3.63 & 0.48 & $0.048^{*}$ \\
\hline & female & 3.89 & 0.52 & & Non-supervisor & 3.84 & 0.62 & \\
\hline
\end{tabular}

Table 3. T-test of gender and supervisory role with perceived work enviroment 


\section{DISCUSSION}

The regression model analyses eleven work environment factors controlling personal and job characteristics. The results indicate that the age of employees is the most powerfull predictor of job satisfaction. This was in line with the previous research done in the field. For instance, the study by Herzberg et al. (1957) was one of the first to suggest that there was a U-shaped relationship between age and job satisfaction. Latter studies have confirmed these findings (Janson \& Martin, 1982; Kacmar \& Ferris, 1989; Clark, Oswald \& Warr, 1996). The explanation for such a relationship is that job satisfaction initially declines until workers approach early 30 s since this is a period when they have the most alternative employment options.
Afterwards, job satisfaction linearly increases until an individual approaches the end of his/her working life. This research also investigates how tenure influences job satisfaction and the perception of the workplace environment. Research results indicate that employees with tenure over 10 years had the highest level of overall job satisfaction and were more satisfied with five out of eleven workplace factors. Similar findings were reached by Sarker et al. (2005) who found there is a significant correlation between tenure and the overall level of job satisfaction. However, the research notes that age acts as a significant modifier on the effects of tenure on satisfaction.

As regards the workplace environment, research results indicate that the most powerful predictor of job satisfaction is recognition, followed by work itself

\begin{tabular}{|c|c|c|c|}
\hline & & Age & Tenure \\
\hline \multirow{2}{*}{ JS } & Pearson Correlation & $.171^{*}$ & .047 \\
\hline & Sig. (2-tailed) & .026 & .546 \\
\hline \multirow{2}{*}{ recognition } & Pearson Correlation & $.181^{*}$ & .133 \\
\hline & Sig. (2-tailed) & .018 & .085 \\
\hline \multirow{2}{*}{ workitself } & Pearson Correlation & .049 & .060 \\
\hline & Sig. (2-tailed) & .531 & .436 \\
\hline \multirow{2}{*}{ advancement } & Pearson Correlation & .001 & $-.208^{* *}$ \\
\hline & Sig. (2-tailed) & .986 & .007 \\
\hline \multirow{2}{*}{ growth } & Pearson Correlation & -.022 & .082 \\
\hline & Sig. (2-tailed) & .781 & .290 \\
\hline \multirow{2}{*}{ responsibility } & Pearson Correlation & -.062 & .039 \\
\hline & Sig. (2-tailed) & .425 & .613 \\
\hline \multirow{2}{*}{ goodfeelings } & Pearson Correlation & -.011 & $-.179^{*}$ \\
\hline & Sig. (2-tailed) & .883 & .020 \\
\hline \multirow{2}{*}{ mission } & Pearson Correlation & -.064 & -.137 \\
\hline & Sig. (2-tailed) & .406 & .075 \\
\hline \multirow{2}{*}{ coworkers } & Pearson Correlation & -.021 & .071 \\
\hline & Sig. (2-tailed) & .791 & .358 \\
\hline \multirow{2}{*}{ supervisor } & Pearson Correlation & $.161^{*}$ & .134 \\
\hline & Sig. (2-tailed) & .037 & .082 \\
\hline \multirow{2}{*}{ salary } & Pearson Correlation & .039 & .009 \\
\hline & Sig. (2-tailed) & .618 & .908 \\
\hline \multirow{2}{*}{ values } & Pearson Correlation & .061 & $-.152^{*}$ \\
\hline & Sig. (2-tailed) & .433 & .049 \\
\hline \multicolumn{4}{|c|}{ **. Correlation is significant at the 0.01 level (2-tailed). } \\
\hline orre & el (2-tailed). & & \\
\hline
\end{tabular}

Table 4. Correlation of age and tenure with perceived work environment and job satisfaction 


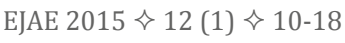

Bojadjiev, M. et al. $\diamond$ Perceived work environment and job satisfaction

\begin{tabular}{|c|c|c|c|c|}
\hline & & Mean & Std. Deviation & Sig. \\
\hline \multirow{5}{*}{ JS } & less than 1 year & 2.89 & 0.69 & \\
\hline & $1-5$ years & 3.14 & 0.64 & \\
\hline & 5-10 years & 3.06 & 0.81 & \\
\hline & more than 10 years & 3.26 & 0.92 & \\
\hline & Total & 3.11 & 0.77 & \\
\hline \multirow{5}{*}{ recognition } & less than 1 year & 2.89 & 1.00 & \\
\hline & $1-5$ years & 3.18 & 0.81 & \\
\hline & $5-10$ years & 3.20 & 0.83 & \\
\hline & more than 10 years & 3.49 & 0.59 & \\
\hline & Total & 3.22 & 0.80 & \\
\hline \multirow{5}{*}{ workitself } & less than 1 year & 3.88 & 0.72 & \\
\hline & $1-5$ years & 3.79 & 0.40 & \\
\hline & $5-10$ years & 3.89 & 0.58 & \\
\hline & more than 10 years & 3.88 & 0.43 & \\
\hline & Total & 3.85 & 0.50 & \\
\hline \multirow{5}{*}{ advancement } & less than 1 year & 3.72 & 0.44 & \\
\hline & $1-5$ years & 3.57 & 0.56 & \\
\hline & 5-10 years & 3.33 & 0.71 & \\
\hline & more than 10 years & 3.23 & 0.71 & \\
\hline & Total & 3.41 & 0.66 & \\
\hline \multirow{5}{*}{ growth } & less than 1 year & 2.73 & 0.59 & \\
\hline & $1-5$ years & 3.13 & 0.67 & \\
\hline & $5-10$ years & 3.10 & 0.66 & \\
\hline & more than 10 years & 3.23 & 0.64 & \\
\hline & Total & 3.11 & 0.66 & \\
\hline \multirow{5}{*}{ responsibility } & less than 1 year & 3.46 & 0.43 & \\
\hline & $1-5$ years & 3.69 & 0.60 & \\
\hline & $5-10$ years & 3.64 & 0.61 & \\
\hline & more than 10 years & 3.73 & 0.43 & \\
\hline & Total & 3.67 & 0.57 & \\
\hline \multirow{5}{*}{ goodfeelings } & less than 1 year & 4.11 & 0.62 & \\
\hline & $1-5$ years & 3.95 & 0.54 & \\
\hline & 5-10 years & 3.77 & 0.65 & \\
\hline & more than 10 years & 3.69 & 0.59 & \\
\hline & Total & 3.84 & 0.61 & \\
\hline \multirow{5}{*}{ mission } & less than 1 year & 4.28 & 0.33 & $*$ \\
\hline & $1-5$ years & 4.08 & 0.52 & \\
\hline & $5-10$ years & 3.90 & 0.50 & \\
\hline & more than 10 years & 4.00 & 0.35 & \\
\hline & Total & 3.99 & 0.49 & \\
\hline \multirow{5}{*}{ coworkers } & less than 1 year & 3.33 & 0.37 & \\
\hline & $1-5$ years & 3.82 & 0.62 & \\
\hline & $5-10$ years & 3.73 & 0.61 & \\
\hline & more than 10 years & 3.88 & 0.20 & \\
\hline & Total & 3.77 & 0.57 & \\
\hline \multirow{5}{*}{ supervisor } & less than 1 year & 3.33 & 0.86 & \\
\hline & $1-5$ years & 3.56 & 0.70 & \\
\hline & $5-10$ years & 3.56 & 0.73 & \\
\hline & more than 10 years & 3.85 & 0.38 & \\
\hline & Total & 3.60 & 0.68 & \\
\hline \multirow{5}{*}{ salary } & less than 1 year & 2.92 & 0.20 & \\
\hline & $1-5$ years & 2.97 & 0.83 & \\
\hline & 5-10 years & 2.84 & 0.64 & \\
\hline & more than 10 years & 3.06 & 0.75 & \\
\hline & Total & 2.92 & 0.72 & \\
\hline \multirow{5}{*}{ values } & less than 1 year & 4.25 & 0.27 & $*$ \\
\hline & $1-5$ years & 3.97 & 0.62 & \\
\hline & 5-10 years & 3.64 & 0.66 & \\
\hline & more than 10 years & 3.90 & 0.32 & \\
\hline & Total & 3.82 & 0.61 & \\
\hline
\end{tabular}

Table 5. Kruskal Wallis test of tenure and perceived work environment and job satisfaction 
and the opportunity for professional advancement. This is also in line with the previous research by McInnis (1999) and Smerek and Peterson (2007) who found that work itself is the most significant predictor of job satisfaction among administration workers. The results of the multiple regression analysis suggest that workplace environment has a much higher influence on job satisfaction compared to personal and job characteristics. Taking into account that the perception of workplace environment can be modified, managers of public administration employees should pay more attention to providing promotion and professional advancement opportunities, allowing for more work autonomy, as well as providing a system of recognition for well performing employees.

\section{CONCLUSIONS}

Given the fact that the perception of workplace environment can be modified, managers of public administration employees should pay more attention to providing promotion and professional advancement opportunities, allowing for more work autonomy, as well as providing a system of recognition for well performing employees.

\section{REFERENCES}

Bowling, N.A. (2010). Effects of Job Satisfaction and Conscientiousness on Extra-Role Behaviors. Journal of Business and Psychology. 25(1), 119-130. DOI: 10.1007/s10869009-9134-0

Bright, L. (2008). Does public service motivation really make a difference on the job satisfaction and turnover intentions of public employees? The American Review of Public Administration. 38(2), 149-166. DOI: 10.1177/0275074008317248

Buelens, M., \& Van den Broeck, H. (2007). An analysis of differences in work motivation between public and private sector organizations. Public administration review. 67(1), 65-74. DOI: 10.1111/j.1540-6210.2006.00697.x

Clark, A., Oswald, A., \& Warr, P. (1996). Is job satisfaction U-shaped in age? Journal of occupational and organizational psychology. 69(1), 57-81. DOI: 10.1111/j.20448325.1996.tb00600.x

Coolican, H. (2004). Research methods and statistics in psychology. London: Hodder \& Stoughton.

DeHart-Davis, L. (2007). The unbureaucratic personality. Public Administration Review. 67(5), 892-903.

George, J.M., \& Jones, G.R. (2008). Understanding and Managing Organizational Behavior. Upper Saddle River, NJ: Prentice Hall.
Goss, K.A. (1999). Volunteering and the long civic generation. Nonprofit and Voluntary Sector Quarterly. 28(4), 378-415. DOI: 10.1177/0899764099284002

Houston, D.J. (2006). „Walking the walk” of public service motivation: Public employees and charitable gifts of time, blood, and money. Journal of Public Administration Research and Theory. 16(1), 67-86. DOI: 10.1093/ jopart/mui028

Jalal Sarker, S., Crossman, A., \& Chinmeteepituck, P. (2003). The relationships of age and length of service with job satisfaction: an examination of hotel employees in Thailand. Journal of Managerial Psychology. 18(7), 745-758. DOI: 10.1108/02683940310502421

Janson, P., \& Martin, J.K. (1982). Job satisfaction and age: A test of two views. Social Forces. 60(4), 1089-1102.

Johnsrud, L.K., \& Rosser, V.J. (2002). Faculty members' morale and their intention to leave: A multilevel explanation. The Journal of Higher Education. 73(4), 518-542.

Jurkiewicz, C.L., \& Giacalone, R.A. (2004). A values framework for measuring the impact of workplace spirituality on organizational performance. Journal of Business Ethics. 49(2), 129-142.

Kacmar, K.M., \& Ferris, G.R. (1991). Perceptions of organizational politics scale (POPS): Development and construct validation. Educational and Psychological Measurement. 51(1), 193-205. DOI: 10.1177/0013164491511019

Kim, S. (2002). Participative Management and Job Satisfaction: Lessons for Management Leadership. Public Administration Review. 62(2), 231-241. DOI: 10.1111/00333352.00173

Locke, E.A. (1976). The Nature and Causes Of Job Satisfaction. In M. D. Dunnette. (Ed.), Handbook of industrial and organizational psychology. Chicago: Rand McNally, pp. 1319-1328.

Kellough, J.E., \& Nigro, L.G. (2006). Civil service reform in the states: Personnel policy and politics at the subnational level. Albany: State University of New York Press.

Reed, P.B., \& Selbee, L.K. (2001). The civic core in Canada: Disproportionality in charitable giving, volunteering, and civic participation. Nonprofit and Voluntary Sector Quarterly. 30(4), 761-780. DOI: 10.1177/0899764001304008

Reiner, M.D., \& Zhao, J. (1999). The Determinants of Job Satisfaction Among United States Air Force Security Police: A Test of Rival Theoretical Predictive Models. Review of Public Personnel Administration. 19(3), 5-18. DOI: 10.1177/0734371X9901900301

Savic, M., Djordjevic, P., Nikolic, D., Mihajlovic, I., \& Zivkovic, Z. (2013). Modeling the influence of EFQM criteria on employees satisfaction and loyalty in transition economy: the study of banking sector in Serbia. Serbian Journal of Management. 9(1), 15-30. DOI:10.5937/sjm9-4972 
Scott, P.G., \& Pandey, S.K. (2005). Red Tape and Public Service Motivation Findings from a National Survey of Managers in State Health and Human Services Agencies. Review of Public Personnel Administration. 25(2), 155180. DOI: 10.1177/0734371X04271526

Smerek, R.E., \& Peterson, M. (2007). Examining Herzberg's theory: Improving job satisfaction among non-academic employees at a university. Research in Higher Education. 48(2), 229-250. DOI: 10.1007/s11162-006-9042-3
Tsai, M.T., \& Huang, C.C. (2008). The Relationship among Ethical Climate Types, Facets of Job Satisfaction, and the Three Components of Organizational Commitment: A Study of Nurses in Taiwan. Journal of Business Ethics. 80(3), 565-581.

Wright, B.E., \& Davis, B.S. (2003). Job Satisfaction in the Public Sector. The American Review of Public Administration. 33(1), 70-90. DOI: 10.1177/0275074002250254

\section{PERCEPCIJA RADNOG OKRUŽENJA I ZADOVOLJSTVA POSLOM MEĐU ZAPOSLENIMA U DRŽAVNOJ UPRAVI}

\section{Rezime:}

Ovaj rad ispituje uticaj radnog okruženja na osećanje zadovoljstva poslom među zaposlenima u državnoj upravi. U njemu se analizira odnos između ličnih karakteristika i karakteristika posla i zadovoljstva poslom. Podaci su prikupljeni na uzorku koji obuhvata 169 zaposlenih u jednoj jedinici lokalne samouprave u Makedoniji. Rezultati istraživanja pokazuju da organizaciona klima i njene komponente mogu u velikoj meri predvideti stepen zadovoljstva poslom među zaposlenima u državnom sektoru. Analiza radnog okruženja ukazuje na to da je priznanje najbolji pokazatelj zadovoljstva poslom među zaposlenima u državnoj upravi, kao i postojanje mogućnosti za profesionalni napredak i unapređenje. Značaj ovog istraživanja ogleda se u njegovom doprinosu širenju znanja i boljem razumevanju determinanti koje mogu pozitivno uticati na zadovoljstvo poslom među zaposlenima u državnoj upravi u zemljama u razvoju.

\section{Ključne reči:}

radno okruženje, zaposleni u državnoj upravi, zadovoljstvo poslom, lične karakteristike, karakteristike posla.

Received: March 26, 2015. Correction: March 27, 2015. Accepted: March 31, 2015. 